\title{
LEUCO-SARCOMA OF THE IRIS
}

BY

\author{
W. S. Duke-Elder and H. B. Stallard \\ LONDON
}

PRIMARY sarcoma of the iris is a relatively rare condition; and although there may be little fundamental pathological difference between those tumours which contain pigment and those which do not, the greater rarity of the leuco-type of sarcoma makes the occurrence of such cases more interesting. Notes of the following case may therefore be of value.

\section{Clinical History.}

The patient, a man aged 60 years, presented himself at the outpatient department at St. George's Hospital complaining of visual failure which had been progressive over some months, affecting especially the left eye. The left lens showed advanced peripheral opacities of the senile type, apart from which the eye was normal. The right eye, however, showed a raised circular tumour about $3 \mathrm{~mm}$. in diameter situated at 9 o'clock on the middle of the anterior surface of the iris (Fig. 1). The iris itself was of a bluish-orange type, and the tumour was of a yellowish-white colour, richly vascularized, and showing on its surface numerous vascular loops. That it had to some extent infiltrated the surrounding tissues was suggested by the fact that the circular outline of the pupil was flattened in this region, and on dilatation of the pupil this section of the iris failed to respond satisfactorily as elsewhere. There was evidence of senile cataract in the lens, less advanced than in the other eye, but the segment opposite the neoplasm showed the most pronounced opacities.

Excision of the eye being refused by the patient, local removal of the neoplasm was attempted in the first place. Under regional anaesthesia a conjunctival flap was dissected up towards the limbus in the region opposite the tumour and a keratome incision at 11 o'clock was carried round the limbus to 7 o'clock with scissors, whereupon the cornea was partially reflected with the conjunctival flap. A large segment of the iris including the neoplasm was then excised, and the conjunctival flap replaced. When the nature of the tumour had been verified by pathological examination, and in consideration of the fact that infiltration was noted in the surrounding tissues of the iris, the eye was removed some days later. Serial sections of the globe showed no other pathological lesion. The eye was excised fourteen months ago, and the patient is still well. 


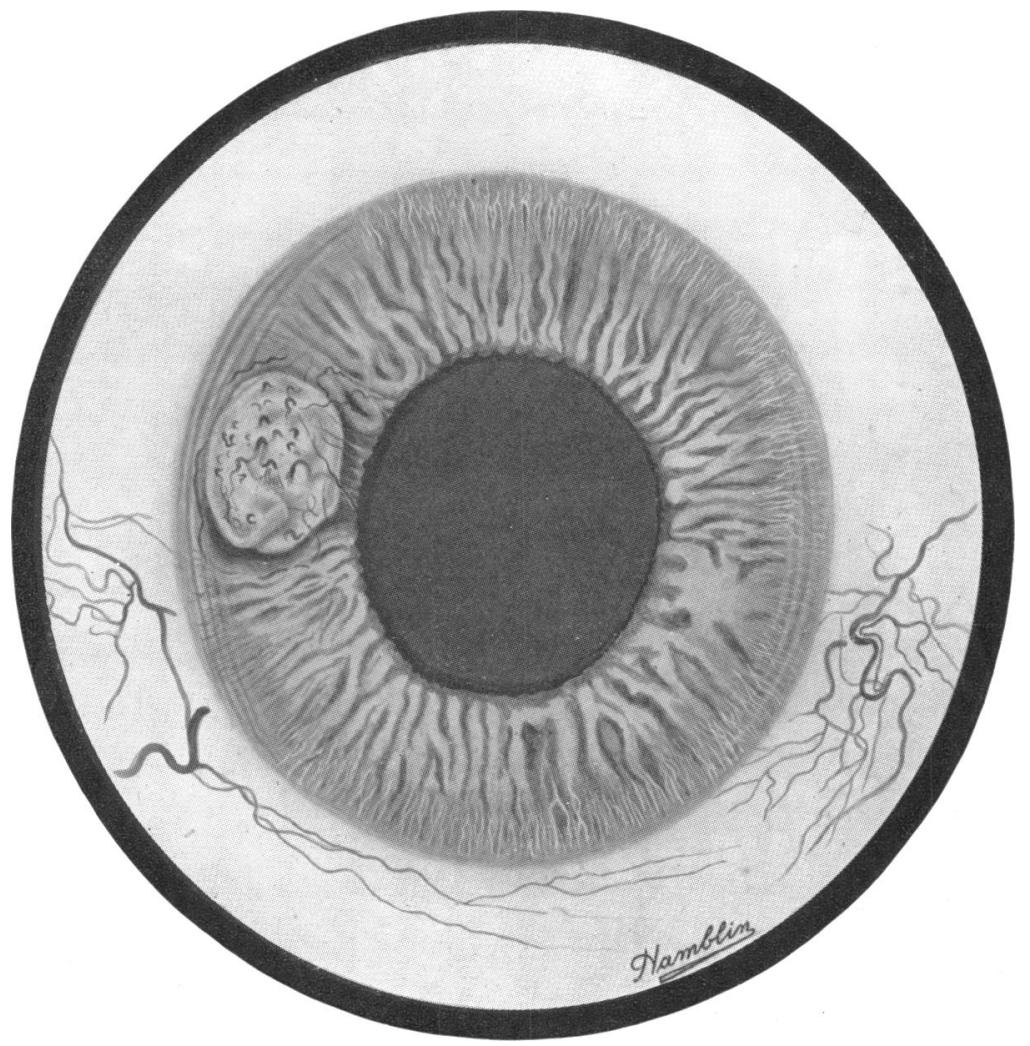

FIg. 1.

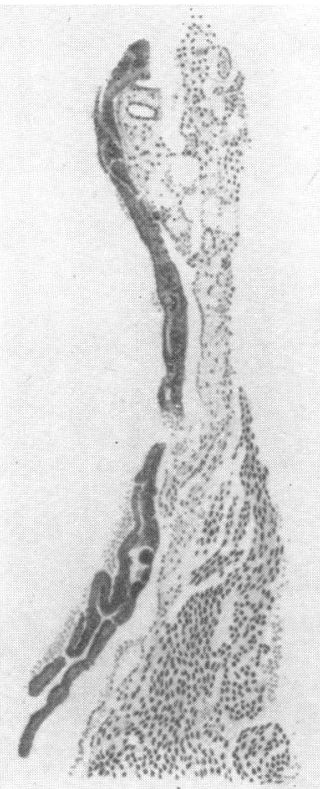

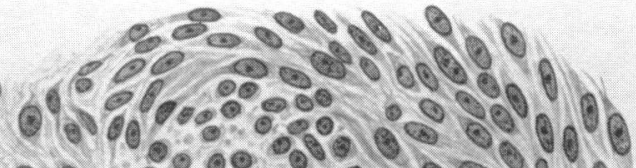

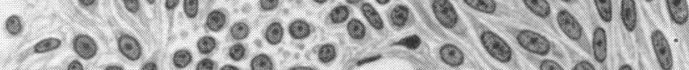
$.00 .0 \% 0.0 \%$ $8.0 \% 0 \%$ \%

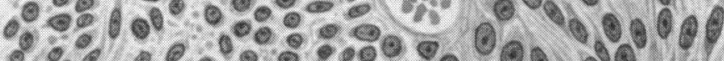

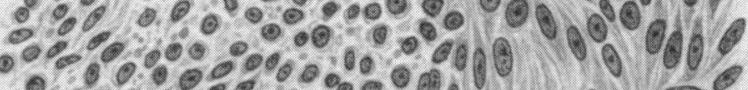
- $60 \%$ \%

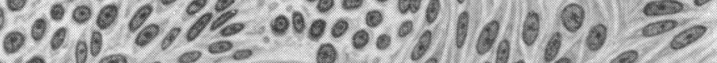

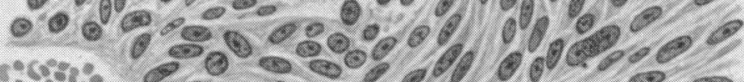

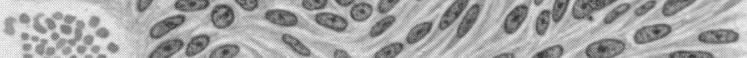

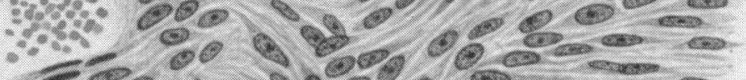

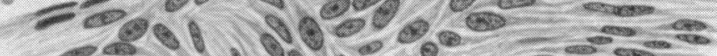

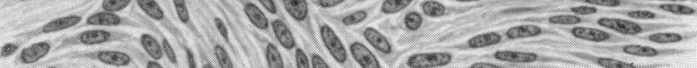


Pathological Findings. (Figs. 2 and 3 ).

The neoplasm was composed of spindle-shaped cells with elongated oval nuclei. The arrangement of the cells was for the most part irregular, but in places they were disposed in interlacing bundles. The entire mass was very cellular and there was no intercellular connective tissue. There was also an absence of mitotic figures. There were many widely dilated blood channels with walls composed of a single layer of endothelial cells resembling embryonic blood vessels. There was no capsule surrounding the neoplasm and it infiltrated the neighbouring iris stroma for some distance. There was no trace of pigment throughout the entire mass, but at the periphery the normal iris stroma was provided with chromatophores.

A search into the literature has revealed only twenty-five cases of this condition reported up to date. An analysis of these cases, together with the one described above, in all twenty-six cases, shows the following facts :-

(i) Sex. 14 males and 12 females.

(ii) Age.

$\begin{array}{rlll}1 \text { to } 10 \text { years } & \ldots & \ldots & 2 \text { patients. } \\ 10 \text { to } 20 \text { years } & \ldots & \ldots & 4 \text { patients. } \\ 20 \text { to } 30 \text { years } & \ldots & \ldots & 4 \text { patients. } \\ 30 \text { to } 40 \text { years } & \ldots & \ldots & 3 \text { patients. } \\ 40 \text { to } 50 \text { years } & \ldots & \ldots & 3 \text { patients. } \\ 50 \text { to } 60 \text { years } & \ldots & \ldots & 6 \text { patients. } \\ 60 \text { to } 70 \text { years } & \ldots & \ldots & 3 \text { patients. } \\ 70 \text { to } 80 \text { years } & \ldots & \ldots & 1 \text { patient. }\end{array}$

The youngest case was a child aged one year, reported by Narog, and the oldest a man aged 75 years.

(iii) History. - The duration of the symptoms and signs which caused the patients to seek advice varied from three weeks to twenty years. Some patients had observed a pigmented spot on the iris for many years. One complained of pain in the affected eye ; in five the visual acuity was diminished, and one was blind. Charnley has reported a case of leuco-sarcoma of the iris where the patient sought advice on account of recurrent attacks of hyphaema. Three patients gave a history of injury, and in three others the affected eye had been inflamed at some previous date. 
(iv) Site of the Tumour.

$\begin{array}{lccc}\text { Lower half of the iris } & \ldots & \ldots & 7 \text { cases. } \\ \text { Temporal half of the iris } \ldots & \ldots & 1 \text { case. } \\ \text { Nasal half of the iris } & \ldots & \ldots & 3 \text { cases. } \\ \text { Upper nasal quadrant } & \ldots & \ldots & 3 \text { cases. } \\ \text { Lower nasal quadrant } & \ldots & \ldots & 4 \text { cases. } \\ \text { Lower temporal quadrant } & \ldots & 8 \text { cases. }\end{array}$

(v) Shape.

$\begin{array}{lllll}\text { Nodular } & \ldots & \ldots & \ldots & 6 \\ \text { Triangular } & \ldots & \ldots & \ldots & 1 \\ \text { Diffuse } & \ldots & \ldots & \ldots & 1 \\ \text { Globular } & \ldots & \ldots & \ldots & 2 \\ \text { Pedunculated } & \ldots & \ldots & \ldots & 1\end{array}$

(vi) Obvious vascularity was remarked upon in 6 cases.

(vii) Microscopic appearances.-Nine specimens were described as consisting of spindle cells, 3 of round cells, and 6 of round and spindle cells mixed together. Of the remainder no definite account of the cytology is given.

The points commented upon were the absence of pigment, of mitotic figures, intercellular tissue, inflammatory reaction and of degenerative changes.

(viii) Complications.-Glaucoma supervened in two cases, while pressure on the lens produced opacities in two further cases. Six cases showed infiltration of the neighbouring structures : in one case infiltration extended into the angle of the anterior chamber: in a second it involved the canal of Schlemm as well ; in a third it had extended inwards to the ciliary body ; in a fourth the sclerotic was involved; in a fifth the cornea; while in the sixth the cornea and the angle of the iris and the ciliary body were involved in the spread of the neoplasm.

(ix) Treatment.-The results of these recorded cases would seem to indicate that if the tumour is localized in the iris in such a manner that its removal by iridectomy can be complete, this localized method of treatment is permissible. Where this has been done no recurrence has been noted for periods up to twelve or eighteen months after the operation, but where the removal is incomplete, the trauma serves as a stimulus for a more rapid growth of the tumour. It would seem that the indications for iridectomy may be stated thus : where the neoplasm is small, well defined, situated at or 
near the pupillary margin of the iris, and is not encroaching on the ciliary border of this tissue; where the intra-ocular tension is normal, the vision of the affected eye is good, and where iridectomy provides facilities for complete removal, a circumstance which can be verified subsequently on pathological examination of the excised portion of the iris. It is obvious that such a method of treatment involves a continuous supervision of the patient afterwards. Where these conditions do not prevail the eye should be excised; a course which is probably the safer in all cases. The prognosis after excision appears to be relatively good provided that the neoplasm does not extend along the perivascular sheaths of the ciliary vessels.

Gifford treated a patient suffering from leuco-sarcoma of the iris by the application of 32 to 48 milligrammes of radium bromide for twenty-five minutes daily for ten days. The radium tube was applied to the outer side of the closed lids in all the treatments except two, when it was held directly across the cornea by subconjunctival sutures for one minute. The neoplasm diminished in size, but the patient insisted on the eye being excised on account of the pain and irritation involved by this method of treatment.

\section{BIBLIOGRAPHY}

Alt.-Amer. Jl. of Ophthal., 1887.

Alt and Culbertson.-Amer. Jl. of Ophthal., p. 33, 1904.

Arganaraz y Belgeri.-Act. y Trab. d. l. Congr. Fac. de Med., Buenos Aires. 1919.

Carter.-Trans. Clin. Soc., Vol. VII, 1874.

Charnley.-Ophthal. Rev., p. 69, 1892.

Dreschfeld. - Lancet, Jan. 16, p. 82, 1875.

Duyse, J. van and Schevensteen, van,-Arch. d'Ophtal., p. 209, 1897.

Gifford.-Arch. of Ophthal., Vol. XLVII, p. 241, 1918.

Kipp.-Arch. of Ophthal., Vol. V, p. 34.

Knapp.-Arch. of Ophthal., Vol. VIII, p. 82.

Limbourg.-Arch. of Ophthal., Vol. XIX, 1890.

Arch. f. Augenheilk., Bd. XXI, S. 394, 1890.

Le Brun.-Ann. d'Ocul., T. IX, p. 209, 1869.

Marshall.-Trans. Ophthal. Soc. U.K., Vol. XVII, p. 30, 1897.

Narog.-Arch. d'Ophtal., August, 1925.

Oemisch.-Inaug. Dissert., Halle, 1892.

Reinhardt.-Inaug. Dissert., Jena, 1904.

Schiötz-Norsk. Mag. f. Laegevid. p. 202, 1908.

St. John Roosa. - Trans: Amer. Ophthal. Soc., p. 14, 1869.

Thalberg.-Arch. of Ophthal., Vol. XIII, 1884. Arch. f. Augenheilk., Bd. XIII, S. 20.

Thompson, A. H.-Trans. Ophthal. Soc. U.K., Vol. XIX, 1899.

Thorington.-Trans. Amer. Ophthal. Soc., Vol. XII, Yt. 2, p. 409, 1910.

Williamson.-Brit. Med. Jl., December, 1893.

Wood and Pusey.-Arch. of Ophthal:, Vol. XXXI, p. 323.

Zellweger.-Klin. Monatsbl. f. Augenheilk., Bd. XXVI, S. 366, 1888. 